\section{$\mathrm{AJ} H$}

Received : 15.12 .2015

Revised : 08.05.2016

Accepted : 17.05.2016

Members of the Research Forum

Associated Authors:

${ }^{1}$ Department of Agronomy,

University of Agricultural Sciences, DHARWAD (KARNATAKA) INDIA

Author for correspondence :

AJIT PANHALE

Department of Agronomy,

University of Agricultural Sciences,

DHARWAD (KARNATAKA) INDIA

Email : ajit.panhale32@gmail.com
THEASIAN JOURNALOF HORTICULTURE

Volume 11 | Issue 1 | June, 2016 | 180-185

Visit us -www.researchjournal.co.in

\title{
Performance of sorghum based intercropping systems under dry sowing and normal sowing conditions
}

\section{AJIT PANHALE, S.S. ANGADI ${ }^{1}$ AND MANJUNATH HEBBAR ${ }^{1}$}

ABSTRACT : A field experiment was conducted at the Main Agricultural Research Station, University of Agricultural Sciences, Dharwad on medium black clayey soil during Kharif 2011 to study the performance of sorghum based intercropping systems under dry and normal sowing conditions. Significantly higher plant height (188.3 cm), LAI (3.21), LAD (60.06 days) and total dry matter production $(182.18 \mathrm{~g})$ were recorded at harvest of sorghum in dry sowing as compared to normal sowing of sorghum. Similarly, plant height $(46.6 \mathrm{~cm}), \mathrm{LAI}(2.38)$ and total dry matter production $(11.73 \mathrm{~g})$ were higher at harvest of legumes in dry sowing as compared to normal sowing of legumes. However, sole sorghum recorded significantly higher LAI (3.41), LAD (60.26 days) and total dry matter production (184.93 g) at harvest which was at par with sorghum intercropped with soybean. Dry sowing enhanced yield of sorghum and legumes by 16.8 and 19.95 per cent, respectively $\left(51.85 \mathrm{q} \mathrm{ha}^{-1}\right.$ and $12.74 \mathrm{q} \mathrm{ha}^{-1}$ grain yield of sorghum and legumes, respectively) over normal sowing of sorghum $\left(43.14 \mathrm{q} \mathrm{ha}^{-1}\right)$ and legumes $(10.30 \mathrm{q} \mathrm{ha}$ $\left.{ }^{1}\right)$. However, sole crop of sorghum recorded significantly higher grain yield $\left(52.48 \mathrm{q} \mathrm{ha}^{-1}\right)$ and stover yield $\left(14.91 \mathrm{tha}^{-1}\right)$ and it was at par with sorghum intercropped with soybean (48.38 $\mathrm{q}$ ha ${ }^{1}$ and $12.51 \mathrm{t} \mathrm{ha}^{-1}$, grain and stover yield, respectively).

KEY WORDS : Dry sowing, Intercropping, Leaf area index, Leaf area duration, Normal sowing

HOW TO CITE THIS ARTICLE : Panhale, Ajit, Angadi, S.S. and Hebbar, Manjunath (2016). Performance of sorghum based intercropping systems under dry sowing and normal sowing conditions. Asian J. Hort., 11(1) : 180-185, DOI : 10.15740/HAS/TAJH/11.1/180-185. 